\title{
A MULHER E O ETERNO FEMININO EM ROSARIO CASTELLANOS
}

\author{
The woman and el eterno femenino in Rosario \\ Castellanos
}

Viviane Bagiotto Botton ${ }^{1}$

\begin{abstract}
RESUMO
Rosario Castellanos é uma das mais eminentes e renomadas escritoras mexicanas do século XX. Com inúmeras obras premiadas e escritas em diferentes gêneros literários (ensaios, contos, romances e peças de teatro) denunciou a opressão das mulheres e a mitificação do feminino por sistemas culturais androcêntricos e por sociedades patriarcais. Assumiu a bandeira feminista dos anos 70 e lutou com sua literatura e com sua força criativa contra a cultura machista de seu país, e inspirou mulheres em todo o continente americano, apesar ter ficado pouco conhecida no Brasil. No livro Mujer que sabe latín (1973) compilou suas ideias mais importantes sobre a subordinação feminina na sociedade, e na peça de teatro El eterno femenino (1975) usou estas concepções como matéria para sua arte, criando de forma irônica e caricatural várias imagens da mulher mexicana a fim de denunciar o sexismo e a hipocrisia sexista do país. Entre uma obra e a outra, retomamos aqui alguns traços da força de sua literatura engajada e sua existência de luta através da palavra pela libertação da mulher e sua subordinação social.
\end{abstract}

Palavras-chave: Rosario Castellanos, mulher, feminismo, literatura, humor.

\section{ABSTRACT}

${ }^{1}$ Doutora em filosofia pela Universidade Nacional Autónoma do México (UNAM), integrante de grupos de discussão e debates sobre corpo e gênero no México e no Brasil. Faz parte do Grupo de Estudos Michel Foucault (PUC/SP) e do laboratório Escritas - filosofia, gênero $e$ psicanálise (UFRJ/CNPq), dentro do qual realiza uma pesquisa sobre gênero e loucura. 
Rosario Castellanos is one of the most eminent Mexican writers of the twentieth century. With numerous award-wining works written in various literary styles (essays, tales, novels and plays), she denounced women's oppression and mysthification of the feminine by androcentric cultural systems and patriarchal societies. She undertook the feminist flag of the seventies and struggled with her literature and creative force against the macho culture of her own country, which inspired women all over the American continent, even though she remained little known in Brazil. In her book Mujer que sabe latin (1973) she compiled her most important ideas about feminine subordination and, in the play El eterno femenino (1975), she employed these conceptions as her own art material, creating, in an ironic and caricature way, several Mexican women's personas with the purpose of denouncing country's sexism and hypocrisy. Between one and another work, we regain some of the strength's features of her committed literature and her existence with her battles with the words to give woman freedom and ending her social subordination.

Keywords: Rosario Castellanos, woman, feminism, literature, humour.

\title{
A mulher e o eterno feminino em Rosario Castellanos
}

\begin{abstract}
ROSARIO CASTELLANOS é hoje uma das grandes referencias da literatura latino-americana, uma das escritoras mexicanas mais citadas e conhecidas daquele país e também aclamada entre os latinistas dos Estados Unidos. Apesar da vasta quantidade de trabalhos em todos os gêneros literários (poesia, contos, ensaios, romances e peças de teatro) ainda é pouco conhecida no Brasil, ficando os estudos de suas obras relegados ao meios intelectualizados e sua leitura a pessoas que dominam o espanhol. ${ }^{2}$ Além de ser conhecida como brilhante escritora e reconhecida com inúmeros prêmios no México e na América Latina - sendo inclusive ela mesma nome de um prêmio literário atualmente —, Castellanos
\end{abstract}

${ }^{2} \mathrm{O}$ fato de não encontramos tradução de sua vasta obra revela o quanto ainda não foi popularizada no Brasil, mas também não parece ser uma autora desconhecida de um certo grupo de leitores locais já que há uma quantidade significativa de artigos acadêmicos sobre sua obra e também de livros de crítica literária traduzidos do inglês que falam delas. 
também era uma intelectual engajada com o problema da opressão das mulheres, tendo ficado conhecida como uma escritora feminista, uma das primeiras em seu país e uma referencia neste gênero no mundo hispânico.

Antes de se consolidar como escritora, ela se formou em filosofia e defendeu uma dissertação de mestrado chamada "Sobre cultura femenina", onde inspirada pela obra de Simone de Beauvoir - que acabava de aparecer na Europa e começava a ecoar na América Latina - questiona a cultura androcêntrica e patriarcal das sociedades ocidentais que abnegam a mulher e condenam sua existência social ao ambiente doméstico excluindo-a da cultura com base no mito de uma natureza feminina que, segundo ela, deve ser desmitificado. A dissertação filosófica de Castellanos, no entanto, demorou muito a ser divulgada e costuma ser considerada como um de seus trabalhos menores cuja relevância foi ofuscada por seus textos literários, e também relegou a própria escritora ao rótulo de autora e não de filósofa, pensadora ou investigadora. Fato que poderia ser explicável simplesmente pelo elevado nível literário de suas obras dignas de prêmio e sua escrita com maturidade — visto que o referido trabalho acadêmico foi elaborado quando a escritora ainda tinha 25 anos - ou simplesmente pelo uso restrito ao qual estão fadados todos os trabalhos acadêmicos. Um detalhe curioso que envolve este texto, porém, é que só foi publicado neste século - pela primeira vez em 2005 - , contrariando inclusive a tendencia do mercado editorial que costuma lançar obras menores de escritores famosos. ${ }^{3}$ Independentemente da separação possível entre uma Rosario Castellanos filósofa e pensadora do feminismo e uma Rosario Castellanos escritora renomada de literatura, suas ficções também falam de mulheres e todos seus trabalhos estão claramente embebidos de suas concepções filosóficas (e políticas), em especial seus questionamentos sobre o que é ser mulher, seu lugar, seu papel e sua

\footnotetext{
3 Sobre a dissertação de mestrado Rosario Castellanos, que não apresentarei em detalhes aqui, sugiro a leitura do artigo de Gabriela Cano: "Rosario Castellanos entre preguntas estúpidas y virtudes locas", onde nos apresenta um panorama detalhado dos argumentos ali presentes. $\quad \mathrm{O} \quad$ artigo está disponível em: https://www.academia.edu/14082945/Rosario_Castellanos_entre_preguntas_estúpidas_y_virtudes_1 ocas .
} 
identidade no mundo, assim como sua crítica à organização sociocultural deste mundo que aliena sua existência. ${ }^{4}$

Frente a esta personagem iconográfica da história da literatura latino-americana e ao conjunto de sua obra, o que proponho alinhavar nestas páginas é, num primeiro momento, um relato que contextualiza a narrativa de Castellanos entre concepções feministas contemporâneas a ela, fazendo aparecer seus posicionamentos político-conceituais como profundamente contestadores da sociedade patriarcal mexicana (e ocidental de modo geral) das décadas de 50, 60 e 70 do século XX onde viveu. A crítica de Rosario Castellanos à sociedade passa pela crítica a modelos de mulher e de feminilidade que ao serem naturalizados através da institucionalização de rituais como os casamentos e os nascimentos, por exemplo, reiteram a abnegação da mulher e sua exclusão de certos espaços em prol de seu aprisionamento em outros, consolidando a posição delas numa escala inferior à vida pública e que apenas tangencia a história e a própria linguagem, ambas feitas por homens e para homens. A escritora mexicana recria em suas obras de ficção estes modelos forjados pelo patriarcado com personagens caricatos e usando o recurso da ironia e inclusive do humor para, assim, denunciar sua construção social e fazer aparente, desnudadas e desmascaradas, as dinâmicas de opressão envolvidas nas relações quotidianas entre homens e mulheres.

Para efetuar este relato, assim como o que se segue dele num segundo momento, apresentarei de modo pontual duas obras da escritora: um ensaio, La mujer y su imagen (1973), e uma peça de teatro, El eterno femenino (1975), enfatizando alguns traços de sua poética literária - muitos deles já conhecidos pelos leitores familiarizados às obras - e contextualizando-os tanto com as

${ }^{4}$ Os trabalhos da escritora costumam ser separados em dois grupos de textos, os que correspondem a seus primeiros textos publicados, cuja temática é indigenista e as narrativas se passam em paisagens rurais; e seus últimos textos, entre os quais o tema da mulher e da oposição cultural entre homens e mulheres em contextos urbanos é recorrente. Apesar desta divisão ser claramente perceptível nos textos em função de diferentes usos de linguagem, construção de personagens e dos temas, o problema em torno do ser mulher também perpassa os trabalhos indigenistas, como defende ela mesma: "Por trás do vestido folclórico há uma preocupação mais profunda e verdadeira: a situação da mulher" (Castellanos, 1975B, p229_ todas as citações aqui são traduções minhas e a referência é da obra original em espanhol). 
questões filosóficas preponderantemente feministas tão caras a esta escritora, quanto com sua trajetória e situação de intelectual, mulher, mãe, casada/divorciada, chiapaneca ${ }^{5}$, mexicana, pessoa pública, etc., em meio a uma época e a um contexto histórico, cultural e social, onde o lugar da mulher ainda era pouco questionado. Apresentarei estas obras de forma cronológica, iniciando com o ensaio, no qual acredito poder ser localizável com mais facilidade algumas das teses centrais do feminismo da escritora, para logo passar à peça de teatro, que por ser mais longa e se referir mais detalhadamente a peculiaridades históricas do México, também será analisada com mais detalhes aqui. Considero, como ver-se-á em breve, que este conto e esta peça podem ser consideradas correlatos literários da argumentação teórica da escritora, ainda que ela não parecesse estar interessa em separar seus textos em teóricos e literários. Tampouco pretendo separá-los, já que um dos objetivos implícitos a este trabalho - e aos meus estudos em torno da obra da autora de modo geral - é resgatar as teses filosóficas desta escritora eclipsadas pelo rótulo de "literata" que lhe foi atribuído com maior peso, fazendo dela uma escritora engajada e não propriamente uma pensadora ou filósofa. Não há dúvidas de que Rosário Castellanos foi uma escritora engajada e assumiu esta postura inclusive por influência das concepções existencialistas às quais ficou muito próxima na última década de sua vida. Recordemos que Sartre em seu livro $O$ que é literatura defendeu a tese de que um escritor não se engaja simplesmente por aderir um movimentos ou outro de luta, mas se engaja à sua obra de modo ativo como uma escolha e com total empenho em viver o que constitui muito mais do que ele mesmo, mas o que constitui a humanidade. (Sartre, 2004, p.29)

${ }^{5}$ Rosario Castellanos viveu a infância e a juventude no estado de Chiapas, no sul do México, de onde saiu por volta dos 20 anos para cursar a faculdade de Filosofia na Universidade Nacional Autónoma do México. Algumas das regiões de Chiapas são cenário de muitas de suas ficções, entre elas o livro de contos Ciudad Real (1960) no qual aborda a conturbada relação entre indígenas e sociedade ex-colonial que os oprimia. O livro, publicado antes da existência do conhecido Exército Zapatista de Libertação Nacional (ELZN), teria inspirado a criação do movimento, segundo confessou o comandante Marcos (líder do referido movimento) em uma de suas conhecidas declarações. 
O que é notável nisso que chamo de situação ${ }^{6}$ à qual a escritora se situa, e que coincide com o lugar onde se situavam as mulheres, especialmente as urbanas da segunda metade do século XX no México e América Latina, é que nestas décadas começava a ser um espaço instável e viria a caracterizar-se como um momento de ruptura significativa com a situação delas nas décadas anteriores, reconfigurando o feminino e a própria condição do ser mulher. Rosario Castellanos parece ter percebido com uma certa antecipação a eminência desta ruptura, que hoje o privilégio da distância nos mostra de modo evidente, e com extrema lucidez e agilidade de quem domina técnicas de análise e crítica social desenvolvendo uma força criativa potente e consolidando com sua literatura uma forma efetiva de reivindicar a urgência de mudança e a libertação da mulher. Habilidosa no manejo da linguagem — o que, segundo sugerem suas biografias, lhe era uma característica desde criança - Castellanos inventou, tanto na ficção quanto em textos jornalísticos — publicando uma coluna periodicamente no jornal El excelsior por muitos anos - , "uma maneira de passar ironicamente e jocosamente através de personagens femininas pela história da mulher no México" (Serna, 2014, p.41)

Análise literária, contextualização histórica e narrativa bibliográfica iguais, portanto, este estudo girará primeiramente em torno das obras referidas acima, para, a partir delas, passar a um segundo momento onde se retomará duas questões importantes que apareciam de modo sutil nas obras aqui comentadas, e que estão conectadas com sua época e também com as teoria as quais ela se filia: (1) o que é ser mulher?ou como é que se tem sugerido que deva ser a mulher no contexto da sociedade em que se vive?; e (2) como devir mulher?, como ter autonomia enquanto tal para que de maneira livre possa ser ela mesma e não o que a sociedade lhe impõe? Ambas perguntas estão no coração destas obras e são respondidas pela escritora de modo sutil e criativo nas entrelinhas de frases que perfilam mulheres e suas vivências, que enunciam suas inquietudes e

${ }^{6}$ Termo que tomo emprestada de Simone de Beauvoir que o empregava referindo-se à volatilidade que se dá ao lugar do feminino e ao conceito de mulher aplicável às pessoas do sexo feminino de uma sociedade. 
escancaram imagens delas que nos afiguram como retratos íntimos que só acessamos graças à lente poderosa utilizada pela autora. São perguntas interconectadas e a segunda delas é consequência necessária e inevitável da resposta da primeira na medida em que só pode ser formulada quando, frente a essas imagens de mulher, aparece a urgência de se reconstruir este ser. Assim, mais do que ser respondida nestas mesmas entrelinhas, a segunda questão é deixada por Rosario Castellanos como uma porta aberta ou um caminho ainda a ser trilhado e para o qual não existe fórmula definida.

A partir da análise destas questões e sua interconexão com as obras aqui expostas e também algumas concepções da escritora que perpassam outros trabalhos e que falarei de modo menos pontual no decorrer deste artigo, considerarei, para concluir, a hipótese de que há um vanguardismo da escritora também em relação ao feminismo de seu tempo, a saber, o da segunda onda. Esta hipótese se assentará sobre o modo como leio a resposta que Castellanos dá à segunda das questões que apresento aqui, a qual, a meu ver, situa a escritora na vanguarda de questões sobre gênero que só aparecerão no final dos anos 70 do século $\mathrm{XX}$ quando se reivindicará mais do que o fim do sexismo e a igualdade entre os gêneros no âmbito social e cultural, se reivindicará a libertação e a desnaturalização de qualquer verdade que caracterize a mulher, à qual é feita não em nome de um fim da mulher, mas em nome da diversidade de ser.

\section{A mulher e sua imagem}

La mujer y su imagen é um ensaio teórico que mais do que assumir uma linha argumentativa segue uma espécie de metodologia de fluxo de consciência, onde insights que surgem a partir de uma reflexão inicial conduzem os temas mais do que uma ordem prédefinida, ainda que Castellanos seja extremamente fiel ao uso de pontuação e períodos semânticos/sintáticos. Em meio a esta leitura, porém, se percebe que há uma estrutura subjacente a este fluxo de temas e que ele tem uma finalidade: promover a libertação da mulher. Antes de entrar na questão sobre libertação de quê, ou do que teria a mulher que se libertar, apresentarei brevemente o contexto da obra e sua publicação. $\mathrm{O}$ ensaio é o primeiro de um grupo deles que foi 
publicado num livro chamado Mujer que sabe Latín (Mulher que sabe latim) onde a escritora tematiza questões sobre as profissionais mulheres no México, e também fora do país, argumentando sobre a situação do sexismo tanto no mundo do trabalho quanto no acesso à educação formal e no ir e vir e existir das mulheres em suas sociedades. Além de alguns artigos de argumentação teórica mais acentuadas, como este que é o primeiro do livro, Castellanos também escreve uma série de textos específicos sobre certas mulheres que ela leu, estudou, e algumas até conheceu, de modo a trazê-las com suas obras e ideias ao México e a seus leitores. Vale lembrar que em 1973 Castellanos já era uma escritora reconhecida, uma intelectual instituída e ocupava o cargo de Embaixadora do México em Israel de 1970 a 1974 quando faleceu prematuramente num acidente doméstico. De Tel Aviv a embaixadora mexicana acompanhou com certa admiração os levantes feministas de 1970 que efervesciam nos Estados Unidos por conta da comemoração dos cinquenta anos da proclamação do direito ao voto feminino naquele país e que protestavam contra a abnegação da mulher pelo patriarcalismo social, as políticas econômicas sexistas do Estado e os machismos quotidianos expressos na não-divisão do trabalho doméstico, responsabilidade sobre os filhos e etc. Frente ao que ela via de longe e que lhe tocava profundamente, a então embaixadora se assumiu como integrante daquelas inquietações e fez uma série de estudos para conhecer a realidade social de suas concidadãs mexicanas. Estes estudos foram utilizados para formular o deste livro, onde mais do que apresentar o que descobriu, Rosario Castellanos os denuncia e expõe argumentos que deverão servir como fundamento e inspiração para as mulheres (mexicanas e outras) na luta por obter os mesmos direitos que os cidadãos homens.

No dia 8 de março de 1971, dois anos antes de Castellanos publicar este apanhado de trabalhos retratando mulheres com instrução (por isso são as que sabem latim) ela lê um discurso em comemoração ao dia internacional da mulher frente ao presidente mexicano da época onde questiona aspectos sexistas e desiguais desta sociedade. Utilizando dados que levantou na pesquisa para o livro e falando das mulheres de forma biográfica, Castellanos as considera símbolo de força e luta feminina e feminista. O discurso tinha o título La abnegación, una virtud loca (a abnegação, uma virtude louca) 
onde caracteriza a abnegação feminina como um valor social dos mexicanos - e também das mexicanas aferradas a ela - que causa um efeito contrário a qualquer aspiração política de formar uma sociedade com equidade e justiça de gênero. Castellanos supõe que o que é considerado uma virtude nesta sociedade se o é, é louca, e para isso há que se criarem leis que lhes sirvam de camisa de força e garantam a igualdade e a liberdade das abnegadas, por mais felizes que estas loucas possam estar com sua situação. O discurso só chegou ao público de forma escrita depois da morte da escritora, em 1975, quando um amigo dela reuniu um pequeno conjunto de seus escritos - em sua maioria feministas - e os publicou sob o título El uso de la palabra (O uso da palavra) para o primeiro aniversário de sua morte. Em 2003, porém, Andrea Reyes resgatou e recompilou de maneira exaustiva os textos jornalísticos da escritora que datam de 1963 a 1974 - por volta de quinhentos ensaios - e então eles foram publicados em três volumes sob o título: Mujer de palabras (Mulher de Palavras) (Castellanos, 2003-2007).

Frente a todos estes trabalhos, justifico a escolha de Mujer $y$ su imagen aqui - inclusive priorizando-o sobre o discurso feito ante o presidente em 1971 e que poderia ser uma escolha óbvia — por ser expressivo de algumas concepções intelectuais de Castellanos que amadureceram desde sua dissertação de mestrado, primeiro trabalho teórico da escritora sobre o feminino, a mulher e sua condição (ou situação), e também, e principalmente, porque creio que nele se sintetiza uma série de argumentos para o feminismo que ela assumia e que transparecem nas entrelinhas de outros de seus trabalhos da época, especialmente os literários. Acredito que a poética feminista que pode ser encontrada em todo um conjunto de escritos de Castellanos está, de algum modo, explícita neste primeiro ensaio, ainda que não se reduza a estas poucas páginas. Como o título já sugere, o ensaio considera a mulher e a imagem dela, começando com as seguintes palavras: "Ao longo da história (...) a mulher foi mais do que um fenômeno da natureza, mais do que um componente da sociedade, mais do que uma criatura humana, um mito."7 espanhol.

${ }^{7}$ Todas as citações aqui são traduções minhas e a referência é da obra original em 
(Castellanos, 1973, p. 9, grifos meus). Tendo afirmado isso, Castellanos passa à explanação do que entende por mito. Faz uma referencia a Simone de Beauvoir, sua grande mestre e inspiração teórica desde os tempos de estudante de filosofia, declarando que "Simone de Beauvoir afirma que o mito implica sempre um sujeito que projeta suas esperanças e seus temores ao céu do transcendente." (Castellanos, 1973, p. 9). Esta projeção da mulher ao transcendente, segundo Castellanos, não é feita por ela mesma, já que ela não tem na história o estatuto de sujeito, mas pelo homem, o qual ao mitificá-la faz dela uma imagem que não é de carne e osso. Esse processo mitificador operaria de modo acumulativo (no tempo) e encobriria as mulheres, o que elas são efetivamente enquanto carne o osso, de camadas densas e opacas de modo que elas mesmas tivessem dificuldades de visualizarem o que são, concebendo assim este mito como uma verdade própria.

Lançadas estas concepções nos primeiros parágrafos do texto e deixando o leitor instigado, Castellanos passa a uma espécie de análise passo a passo que mostraria em que se constitui a formulação deste mito e como através dele as mulheres teriam sido ao longo da história reduzidas a um princípio, e só a um princípio, o qual se opõe ao masculino (que é princípio mas também materialidade) e, por conta disso, se encontram perdidas, desgarradas, vencidas, mas não aniquiladas, existindo nelas, apesar de tudo, algo que sobrevive e que ameaçaria sua mitificação e também os autores dela, os homens. $\mathrm{O}$ ensaio segue denso e para os conhecedores das teses de Beauvoir e do existencialismo desta e de seu marido (Sartre), algumas conexões poderão parecer óbvias. Ainda neste trecho inicial, a autora deixa clara sua filiação à obra $O$ segundo sexo afirmando:

O criador e o espectador do mito, já não vêem na mulher alguém de carne e osso, com certas características biológicas, fisiológicas e psicológicas; e ainda menos vêem nela as qualidades de uma pessoa que lhes é semelhante em dignidade mesmo que diferente na conduta, porém só sinalizam a incarnação de algum princípio, geralmente maléfico, fundamentalmente antagônico (Castellanos, 1973, p. 9) 
Ao defender que criadores e espectadores do mito mulher só vêem nas mulheres em particular, em cada uma delas, a incarnação de um ideal ou princípio que lhes é fundamentalmente antagônico, ou seja, oposto, que é o outro deles, Castellanos está sugerindo (na esteira das teorias da pensadora existencialista francesa) que os discursos que formam a mulher lhe colocam necessariamente no lugar do Outro do homem, a mulher é o Outro do homem assim como o Outro da cultura e da história. "A história", afirma Castellanos entre os parênteses que deixei sinalizados com reticencias na primeira citação que fiz deste texto - "é o arquivo dos fatos cumpridos pelo homem, e tudo o que fica fora dele pertence ao reino da conjetura, da fábula, da lenda, da mentira" (Castellanos, 1973, p. 9). A prova disso, para a escritora são todas as analogias que a linguagem tem permitido ao longo dos tempos entre estas duas forças supostamente antagônicas e hierárquicas: "Sol que vivifica e mar que acolhe sua dádiva; vento que espalha a semente sobre a terra que se abre para a germinação; mundo que impõe a ordem sobre o caos;..." (Castellanos, 1973, p. 10). Esta alteridade subordinada expressa nestes trechos, portanto, é o que reifica a posição secundária da mulher no mundo. Como afirmava Beauvoir, "a mulher determina-se e diferencia-se em relação ao homem e não este em relação a ela; a fêmea é o inessencial perante o essencial. O homem é o Sujeito, o Absoluto; ela é o Outro" (Beauvoir, 1970, p.10).

Apresentadas essas ideias iniciais e preponderantemente existencialistas, volto à questão que deixei em aberto antes de seguir considerando a obra em seu contexto biográfico e conceitual e recoloco a pergunta: de que a mulher teria que se libertar? A resposta parece já estar indicada na ênfase que encontramos na referência à alteridade subordinada que Castellanos elabora quase em homenagem a Beauvoir. Para Castellanos a mulher (no singular) e as mulheres (no plural e em sua diversidade) precisam se libertar do mito que a cultura androcêntrica que rege a linguagem e a historia fez dela [como mulher] para oprimir elas [as mulheres]; precisam se libertar da transcendência que lhes faz ser mais um princípio e menos pessoas, corpos, existências, particularidades. As características deste mito, segundo ela, são a passividade e a abnegação, as quais muitas vezes são aclamadas pelas próprias mulheres como características de sua natureza e também como seu dever moral e valor que precisam 
seguir. Outras vezes, ou outras delas, não assumem esse mito, porém, se acomodam nele porque é preciso, segundo ela, uma força muito grande para introduzir um produto feminino num universo de homens.

$\mathrm{Na}$ sua dissertação de mestrado, ao fazer referência às mulheres que chegam a adentrar o universo masculino da erudição e da administração pública, da política e da cultura, Castellanos perguntava como certas mulheres teriam conseguido introduzir seu contrabando - entendido aqui como um produto de mulheres, mais do que suas existências individuais - em fronteiras tão vigiadas? "O que lhes teria impulsado de maneira tão irresistível a se arriscarem para ser contrabandistas?" (Castellanos, p.23), perguntava ela na dissertação. A imagem destas contrabandistas parece recobrar cor no ensaio La mujer y su imagem quando a escritora considera que mesmo na dinâmica mitificadora que impõe uma relação de subordinação da mulher-mito ao homem-coisa-de-fato,

o triunfo [do dominador] para ser absoluto, requereria a abolição de seu contrário. Como esta exigência não acontece, o vencedor - que pousa sua bota na jugular do inimigo derrubado - sente, em cada palpitação, uma ameaça; em cada gesto, uma eminência de fuga; em cada respirada, uma tentativa de sublevação. E o medo engendra novos delírios monstruosos. Sonhos onde o mar devora o sol na hora do crepúsculo; onde a terra se nutre de desperdícios e de cadáveres; onde o caos se desencadeia liberando um enorme impulso orgiástico que excita a licença dos elementos, que desata os poderes de aniquilação, que confere o cetro da plenitude às trevas do nada (Castellanos, 1973, p. 10).

Para Castellanos, se o processo de mitificação não chega a aniquilar a mulher, ao menos não algumas mulheres que tentam viver sua força e adentram territórios não destinados a elas, o medo que estes exemplos de força causam à cultura masculina e masculinizada estimula os criadores desta a assumirem atitudes que reforcem o mito da mulher, mesmo que seja por meio da aclamação e valorização delas. Assim, atitudes pseudovoloradoras que representam falsas ambivalências criadas nesta cultura, ao valorizarem as mulheres, ao sacralizá-las, lhes estariam subjugando e separando num domínio de santos, de seres de espírito puro, e, portanto, lhes retirando do mundo e restringindo-lhes a possibilidade de serem o que quiserem ser. 
O ensaio traz exemplos bem elaborados apresentados de modo não dedutivo e nem explicativos, mas de forma linear e bem humorada. Num fluxo que passa da descrição de como funcionam as ataduras para diminuir os pés das mulheres chinesas às unhas longas que impedem o uso das mãos, aos sapatos de salto agulha que não as permite caminhar, ao tempo que se lhes exige para a estética do cabelo, Castellanos pinta imagens de uma submissão cultural feminina que passa por seus corpos. Apesar da profundidade destas ideias que explicitam o feminismo da autora, o ensaio não soa como uma denuncia desoladora, mas como um retrato ou imagem - como nos prevenia o título do ensaio - que inclusive pode ser engraçado e exagerado. Não há nele, porém, a elaboração de caricaturas, como é comum nas ficções de Castelhanos e como haverá na peça que considerarei a seguir. O que encontramos neste ensaio é uma espécie de postura um pouco burlona, que é uma das características da escrita da autora, mas que se identifica no texto de maneira sutil. Em meio a tal sutileza, ela enfatiza o quanto a situação da mulher - falando dela de modo geral e generalizante - depende de que reduzam o corpo de mulheres à uma ideia e imagem de frágilidade, de sexo frágil. Sem citar Simone de Beauvoir nesta referência, Rosario Castellanos retoma com isso outro dos argumentos centrais da pensadora francesa e o associa a uma figura elaborada por Virginia Woolf : o anjo do lar. Evoca assim, a partir da imagem que toma emprestado da escritora inglesa, um retrato do papel secundário da mulher na vida pública enfatizando a responsabilidade que se costuma dar a ela à manutenção da vida, na medida em que se lhe atribui a tarefa de manter a casa e a ordem do doméstico. Se é na casa que se preparam os alimentos, que se lavam e passam as roupas para o trabalho e o lazer, que é onde se descansa e dorme de modo protegido e a fim de estar bem para viver no espaço público, ao fazê-la responsável por este lugar, a sociedade estaria criando a ilusão de que valoriza a mulher. Só que nessa responsabilização, denuncia Castellanos, também se encontra sua condenação e prisão. ${ }^{8} \mathrm{O}$ ponto culminante da atribuição de uma

${ }^{8}$ Castellanos tem um conto muito comentado por ser um dos mais feministas dela que se chama lección de cocina (lição de cozinha) onde enfatiza de modo mais detalhado como o lugar da mulher na cozinha é parte constitutiva de uma responsabilidade que a prende e ofusca seu verdadeiro ser. 
responsabilidade pela ordem e manutenção da vida à mulher, no entanto, não está no fato de que as responsabilizem pelo preparo dos alimentos, ou pela manutenção das condições adequadas para que a vida de todos na família, especialmente os homens, tenha suporte para que possam atuar no domínio público, mas está no fato de que é ali que se criam os filhos e que são as mulheres que reproduzem - são responsáveis por - a nova geração de humanos do mundo.

Permito-me fazer uma parada mais delongada neste traço da imagem que Castellanos está pintando da mulher, para, uma vez mais, relacionar sua obra à da filósofa Simone de Beauvoir, quem já considerava o tema da maternidade como um problema importante e também para retomar dois momentos do pensamento da própria escritora mexicana. Como já foi mencionado algumas vezes aqui, na dissertação de mestrado da escritora encontramos concepções que expressam uma primeira leitura que a jovem estudante fez do livro $O$ segundo Sexo de Beauvoir. Naquele trabalho, porém, a pergunta inicial da jovem filósofa em vias de formação era: existe uma cultura feminina? Para a qual ela respondia de modo analítico, como deve ser um bom trabalho acadêmico, passando por filósofos que teriam elaborado teorias convincentes e coerentes - ao menos para suas épocas - sobre a inferioridade da mulher. Passados estes passos, a estudante assumia uma postura idealista, inspirada em alguns autores do Idealismo alemão (que ela cita no trabalho), para defender que haveria um domínio humano paralelo ao das produções culturais e tido como elevado na sociedade, onde as mulheres teriam a mesma relevância que têm os homens no âmbito da cultura. Este espaço ou domínio delas, seria o da maternidade e onde, através desta, as mulheres estariam num mesmo nível que o dos homens e poderiam alcançar o âmbito dos grandes feitos e da imortalidade. Exposto aqui de modo muito esquemático e sob o risco de ser redutor, este espaço de equivalência (mas não de equidade) das mulheres em relação aos homens que ela defendia como correlativo da cultura, era fruto, a meu ver, de uma leitura rápida, jovem e inicial, da passagem do texto de Beauvoir onde esta lança a pergunta sobre por que as mulheres não faziam da maternidade um pedestal de força, poder e autonomia? (Beauvoir, 20, p. 83). Esta concepção sobre a maternidade como redentora que pode ser encontrada no referido trabalho acadêmico de Castellanos, no entanto, é modificada em seus trabalhos maduros, 
especialmente este. Segundo Gabriela Cano (2005), isso se deve ao fato da escritora ter assumido como seu o pensamento existencialista e ter abandono concepções idealistas e de tons metafísicos. Dito de outro modo, Castellanos teria relido o livro de Beauvoir com mais cuidado e maturidade, assim como teria assumido outras ideias desta pensadora, de seus pares, e especialmente haveria atualizado suas concepções a partir das influências que teve das ondas feministas de sua época. Sobre esta mudança a própria escritora confessa:

$\mathrm{O}$ que em um momento nos pareceu como um destino imutável - o ser homem e o ser mulher como um conjunto de qualidades essenciais cuja constância não pode ter mais exceção do que a anormalidade - se torna subitamente uma relação dinâmica onde os atributos de cada um de seus componentes dependem de uma série de circunstâncias econômicas e políticas. (Castellanos citada por Cano, 2005, p. 27)

Esta concepção existencialista feminista madura de Castellanos que evoco aqui, teria levado a escritora não só a modificar sua concepção sobre a maternidade num âmbito conceitual, como teria refinado sua crítica política ao patriarcado e androcentrismo, assim como impulsionou o engajamento dela para a mudança e a reestruturação de sociedades onde as mulheres se encontravam em situação de opressão. Com base neste engajamento, a escritora passou a defender que a maternidade também é uma maneira de manter as mulheres subordinadas, relegadas ao lar e fora do mundo do trabalho e da sociedade masculinizada. Frente ao seu aprisionamento em casa e a tantas manobras de subordinação, ela também argumentava que é com a maternidade que as sociedades machistas oferecem às mulheres o direito à cidadania."Se a maternidade", afirma ela, ...

...não fosse mais do que uma explosão física, como entre os animais, seria uma anátema. Porém não é sequer uma eclosão física porque isso implicaria uma euforia sem atenuantes que está muito longe do espírito que a sociedade imbuiu na perpetuação da vida" (Castellanos, 1973, p. 15) 
O que é a maternidade então? O que fez-se dela para estar de acordo com o espírito das sociedades? São algumas das questões que Castellanos vai respondendo, ainda que não as coloque como interrogativas explícitas na sequência de seu ensaio. " Nove intermináveis meses de repouso, de dependência dos demais, de precauções, de ritos de tabus. A prenhez é uma enfermidade cujo desenlace é sempre catastrófico para quem a padece" (Castellanos, 1973, p. 15), afirma a escritora. Além da referência à atribuição de dor à gravidez mesmo quando não é dolorosa, e de sua qualificação como doença, Castellanos vai salientar também como à mulher é atribuída a educação dos filhos, e nos conta que se uma mulher depois de parir volta ao trabalho, a sociedade inteira passa a lhe dar atributos de egoísta e insensível. Castellanos inclusive faz burlas sobre as celebrações feitas nos dias das mães e às ideias de "instinto materno", "amor materno" e "coração de mãe", que seriam todas notas de um mito cultural que atravessaria as mulheres, especialmente as mexicanas, de cima para baixo desde que nasceram - recordemos que o dia das mães no México não é só um dia festivo, é um feriado nacional ao lado de outros como o dia da independência do país ou o dia da criança.

Deixando o tema da maternidade, Castellanos passa à finalização do ensaio onde assume que a mitificação que abnega a mulher nas sociedades passa por mecanismos socioculturais e políticos de subordinação estética, como bem mostram seus exemplos sobre os modelos de beleza atribuídos ao feminino; de subordinação ética, como bem se exemplifica em toda a moralidade que envolve a maternidade e a responsabilidade pela vida; e de subordinação intelectual, onde ela retoma alguns nomes que já tinha analisado em sua dissertação de mestrado com suas teses sobre a inferioridade intelectual das mulheres em relação aos homens. Sobre este último mecanismo, Castellanos salienta o nome de Moebius, quem teria desenvolvido com tenacidade germânica, burla-se ela, um tratado sobre a debilidade mental feminina. Também apresenta uma longa citação em bloco de um "senhor ilustre", burlando-se uma vez mais, que se chamaria Neuville, e que quase ninguém saberia quem é, que teria tentado conceder às mulheres alguma licença de possessão de inteligência ao reconhecer que algumas delas ao produzirem engenhocas impressionantes, como pentes que injetam líquido 
diretamente no couro cabeludo para uso de cabeleireiros, alongadores de cigarro, aparelhos de dança,... teriam um cérebro menos imbecil.

Frente estas três esferas e suas ações que tratam de coibir a existência livre das mulheres, a escritora passará a defender que ainda assim e apesar de tudo, as mulheres seguem mulheres e que o exemplo disso é que muitas delas, dentre as quais cita Soror Juana (a conhecida poeta mexicana), Anna Karenina (personagem de Tolstoi), Ana de Ozores (personagem de Leopoldo Alas), Hedda Gabler (peça de Ibsen) e uma série de outras imagens de mulheres conhecidas na literatura, não se deixaram esmagar por ser mulher e também por terem aparecido enquanto tal em meio a culturas masculinas e sido imagens iconográficas de mulher ali." "Cada uma delas e a sua maneira e em suas circunstâncias nega o convencional, faz estremecer as bases do estabelecido, pára de cabeça as hierarquias e consegue a realização do autêntico" (Castellanos, 1973, p. 18), afirma Castellanos.

Disso se segue sua conclusão: é tomando consciência de sua subordinação, tomando a vida em mãos, por meio de uma decisão, que a mulher consegue rejeitar as imagens que fazem dela e chegar a sua substância última, ao que ela mesma é, ao que resulta da conciliação de seus apetites mais secretos com suas estruturas mais verdadeiras. Uma tese que Castellanos apresenta como via para solucionar a mitificação da mulher e que se expressa como existencialista e localizada no contexto da década de 70 (do século $\mathrm{XX}$ ), ao defender que a tomada de consciência de sua condição é um primeiro passo para a libertação desta condição. Neste sentido, Castellanos também defende que a libertação deve caminhar para algo mais verdadeiro e essencial, que já está dado nas mulheres e que constitui sua essência, mas que, por enquanto, não estaria formulado, cabendo a ela formular.

A façanha de converter-se no que se é (seja qual for seu sexo e suas condições) não é unicamente a descoberta dos traços

${ }^{9}$ É extremamente pertinente e intrigante nesta passagem, ainda que não seja possível desenvolver este aspecto aqui, como Castellanos evoca imagens de grandes mulheres da ficção num mesmo nível que se evocam personagens da história, como o faz com Soror Juana Inés de la Cruz, uma poeta que aparece ao lado de mulheres ficcionais como Anna Karenina. 
essenciais sob a espora da paixão, da insatisfação ou do aborrecimento, mas principalmente o rechaço dessas falsas imagens que os falsos espelhos oferecem à mulher nas estreitas galerias onde suas vidas transcorrem (Castellanos, 1973, p. 18).

É com essas imagens de mulheres em espelhos e que estão projetadas, como hologramas sem carne e sem ossos, sem realidade essencial, a fim de servirem como modelos de mulher, que passo ao segundo trabalho de Castellanos que propus comentar aqui, para somente depois, em um segundo momento, retomar essa ideia de que há algo substancial de si que pode ser desvelado e deixado em liberdade.

\section{O eterno feminino}

El eterno femenino (1975) é uma obra de teatro que Castellanos não escreveu para ser publicada, sendo ela conhecida como texto somente depois da morte da autora, ocorrida no ano anterior à publicação. A peça teria sido um convite feito por seus amigos - a atriz de teatro Emma Teresa Armendáriz e o diretor de teatro Rafael López Miarnau - em 1970 e ao qual a escritora teria recusado inicialmente por estar preparando sua mudança para Tel Aviv - onde iria ocupar o cargo de embaixadora do México - e também por ter-se considerado incapaz da façanha. Depois de negociações e estando ela instalada em Israel, aceitou a tarefa mas se assegurou de que sua cenografia fosse feita por um dramaturgo. Terminou a peça em 1973 e declarando-se preocupada pela reação que poderia causar ao público, pediu que fosse uma peça de humor e felicidade, inclusive recomendando isso na carta que acompanha o manuscrito. "Eu agradeceria que toda a equipe de trabalho não esquecesse a frase de Cortázar que bem poderia ter me servido de epígrafe e que afirma que o riso cavou mais túneis do que as lágrimas" (Castellanos, 1975, p.135), escrevia ela na carta. Além deste pedido também pede ao cenógrafo que componha cenários que tendam ao exagero mais do que à realidade e aos atores que lembrem que não se trata de personagens, mas de situações encenadas. Muitos dos detalhes da primeira montagem e das características desta peça em relação a outros momentos e obras da 
autora podem ser consultadas na apresentação do livro publicado pela editora $\mathrm{FCE},{ }^{10}$ onde encontramos também a hipótese, feita por Raul Ortiz, de que seja uma obra diferente e nova do ponto de vista da perspectiva mas que considera a mesma interrogação que atravessava todas as obras da autora: a rejeição a todo comportamento engessado e convencional.

A que se deve essa nova perspectiva? A que se deve a preocupação da autora para que seja uma peça alegre e que utilize o recurso do humor e do exagero em lugar das lágrimas e da realidade? Seria somente uma maneira de se salvar da má recepção do público?

Castellanos prezava seus leitores mas já estava suficientemente estabelecida para suportar as críticas que muitas vezes já havia recebido por suas posturas feministas. A nova perspectiva, que a meu ver não é assim tão nova, parece se fundamentar no fato de que Castellanos nos coloca como espectadores/leitores a uma distância maior dos personagens e cenas do que em outras obras, produzindo assim uma visão panorâmica dos problemas que aborda. Esta distância que o panorama cria parece ser o que dá ao feminino ali representado a visão do eterno. O eterno do feminino que ela representa na peça pode ser lido com a chave do ensaio La mujer y su imagen, que acabei de apresentar, e as imagens de cada situação que se encena é a repetição e a reiteração de formas de ser que justamente por isso se fazem eternas.

Castellanos percorre imagens específicas de personagens mulheres, de situações mulheres, de retratos e reflexos mulheres. $\mathrm{O}$ palco, nesta peça, é o espelho falso que projeta às mulheres - e não aos homens - suas igualmente falsas imagens nas estreitas galerias onde suas vidas transcorrem. $\mathrm{O}$ humor e o riso são o que dão a dimensão falsa desses espelhos, é a moldura Kitsch e brega das imagens que permite à espectadora perceber que se trata de uma obra falsa. Os traços de humor e o exagero, assim como a visão em

${ }^{10}$ El fondo de cultura econômica FCE é mais do que uma editora, é uma fundação subsidiada por fundos públicos e privados com sedes em toda a América Latina (inclusive contou com uma livraria em São Paulo que fechou em 2017) e cujo compromisso é com a difusão de textos literários e críticos. Esta detém todos os direitos da obra da autora assim como conta com uma livraria-centro cultural com o nome de Rosário Castellanos, onde além de disponibilizar todo o conjunto de sua obra também disponibiliza os filmes que foram feitos baseados em seus livros. 
perspectiva, não são novidades nos trabalhos da escritora e inclusive é conhecido que a ironia é um de seus recursos recorrentes para pintar caricaturas que tocam problemas nevrálgicos da sociedade moderna, como o sexismo e o racismo, por exemplo. O que parece novo na peça, ou pelo menos é um novo matiz, é esta alegria e riso que deve causar ao público como um objetivo pré-fixado. Se ao ler contos como os do livro Álbun de família (1971) já ríamos com as sutilezas das analogias realizadas naquelas linhas, esse riso era algo que a escritora podia mais ou menos supor ao usar suas palavras que seriam lidas ou ouvidas enquanto texto, porém, o que acontece com a peça é que Castellanos fornece palavras e texto ao espectador/leitor mas não será ela quem fornecerá seu arranjo. Daí uma das preocupações da escritora: não dar ao público palavras que o levem a conceber a situação como particularmente triste, mas como globalmente hilária. Nisso consiste uma das forças da escrita de Castellanos como feminista, uma força que não critica a abnegação feminina somente por ser triste para as mulheres, mas por ser bizarra e trágica - tão trágica que causa riso - para toda a humanidade.

Resumidamente, a peça começa num salão de beleza onde Lupita, a personagem principal e que protagonizará todas as cenas, vai se embelezar para seu casamento. Já no salão e pronta para enfiar a cabeça num daqueles modeladores de cabelo típicos dos anos $70-$ e que hoje vemos nas séries retrôs da Netflix -, heis que aparece um vendedor desses mesmos aparelhos com uma novidade: o modelador que produz sonhos à mulher que o usa enquanto fica ali sentada. $\mathrm{O}$ aparelho promete suprir um problema fundamental, a saber, o da possibilidade de que ao ficar sentada sem fazer nada se coloque a pensar. Assim, sonhar é uma solução útil que evita que a mulher pense. Lupita é convidada a experimentar a engenhoca e o que se segue disso são os sonhos dela, os quais a levam para o futuro, para o que ela será ao deixar de ser Senhorita para ser Senhora, quando for mãe ou quando não o for, quando decidir se divorciar, quando decidir não se casar, quando decidir trabalhar, quando ficar velha... Lupita passeará por meio destes sonhos por um universo de possibilidades onde cada uma delas simboliza uma mulher caricatural, uma imagem refletida da mulher mexicana, que desnudará a hipocrisia com a qual esta sociedade modela mulheres, as oprime e ainda as premia por isso. Ao final de cada ato, que coincide com uma situação possível de vida 
futura para Lupita, ela acorda e se desespera jocosamente, bufonicamente, e pede que lhe dêem outro penteado pois aquele ela não quer. Depois de muitas tentativas e tantos sonhos angustiantes, apesar de engraçados para quem os olha de fora, Lupita se irrita e toma coragem para ir embora do salão, deixar a máquina que lhe incute sonhos e preocupada com o atraso sai correndo para casa afirmando que vai improvisar um penteado por conta própria.

Guadalupe é o nome da santa padroeira do México. A Virgem de Guadalupe, que em português se traduz por Nossa Senhora de Guadalupe, com a perda desta referência à sua não-iniciação à sexualidade e a referência à senhora que deu à luz um filho sem ser defraudada em sua natureza de mulher pura, e que a língua espanhola conserva, é uma das referências mais importantes de mulher para o México. Grande parte das crianças nascidas mulher no país recebem o nome próprio de Guadalupe, cujo diminutivo é Lupita ou Lupe, especialmente as devotas ou as que tiveram que apelar para a divindade em algum momento da gestação. Lupita é a imagem mais caricatural de mulher sagrada de todo México, e talvez de toda América Latina, ela é a mãe bondosa que não incorreu em pecado (sexual) para dar à luz o filho de deus, e também é a aparição da Virgem Maria naquele espaço do globo, que ao aparecer a um "índio" é também a mãe de todos, a mãe do povo. Castellanos se refere de passagem a esta imagem ao dar o nome a sua protagonista, pois não é o imaginário religioso do povo mexicano que quer resgatar - fosse para criticar ou para aclamar - , mas o que este povo tem feito da mulher. Ela quer desenhar, retratar, pintar, o que têm sido a mulher neste espaço geográfico e, principalmente, neste inconsciente coletivo que sacraliza mães, que recrimina prostitutas, que condena à solidão escritoras, que faz de suas heroínas da revolução simples sombras de seus maridos, que mitifica a mulher tolhindo as mulheres de sua potencialidade como humanas e sua liberdade.

Mais detidamente, exporei agora algumas dessas imagens de mulher que encontramos na peça e como suas posições formulam um retrato da sociedade. No primeiro ato, temos de antemão três imagens de mulher, Lupita, nossa protagonista, que é uma jovem (supostamente) virgem que se prepara para ser uma dama da sociedade; a dona do salão que é viúva, que trabalha, administra o negócio, e não é, ou já não é, uma dama da sociedade (classe média) 
mexicana, já que está ali para prestar um serviço e não disfruta do privilégio de ser sustentada pelo marido, privilégio que têm suas clientes e que ela admira e reforça; e a cabeleireira, que é de nível mais baixo que a dona do salão - isso se expressa em sua linguagem, quando dá opinião sobre tudo, se intromete na conversa com o vendedor, com as clientes - mas ainda assim é uma profissional valorizada e não está no nível de uma empregada doméstica, que seria nesta hierarquia o nível mais baixo que ocupa uma mulher naquele cenário, e que só aparecerá em outras cenas. ${ }^{11}$ Quando a cabeleireira entra na conversa com o vendedor, a proprietária não se atreve a protestar e a enviá-la a seu lugar de empregada, pois confessa ter medo de que ninguém mais lhe sirva, reclamando assim da decadência da moral no país, assim como da sua própria, refém dos bons modos que precisa ter com os serviçais rudes para que não a abandonem. No confronto entre a patroa e a empregada, Castellanos já traz à tona muitos dos traços da sociedade que quer denudar e mostrar como hipócrita no palco, como a menção que faz aos modos de linguagem de ambas e, especialmente, às queixas da dona do salão como uma mulher conservadora e em decadência. $\mathrm{O}$ vendedor, um dos poucos personagens homens que aparecerá em toda a peça, argumenta em favor da venda da engenhoca, perguntando à dona quantas horas por semana fica uma mulher com a cabeça enfiada no modelador de cabelos. Ela responde dizendo que depende da cabeça, sinalizando que algumas vêm todos os dias. $\mathrm{O}$ vendedor calcula o tempo e impressionado diz: "Isso faz em média 52 horas ao ano, 52 horas de inferno!" $\mathrm{E}$ a dona lhe responde: “ há que sofrer para merecer, não acha? Aos que querem azul celeste, que o paguem" (Castellanos, 1975, 180). O vendedor promete a Lupita que seu sonho será a sua Lua de mel, que nele ela será linda, será invejada pelas outras mulheres, seu marido terá um salário ótimo, ela terá

11 Sobre a situação da empregada doméstica e as diaristas, que no México são frequentemente indígenas e de classes baixas, Castellanos reflete com profundidade em outro de seus ensaios, onde sinaliza para o fato de além de ser oprimida por outras mulheres que na cadeia de subordinação se encontram acima delas, também são elementos necessários para que as mulheres que usam seus serviços não lutem pela divisão do trabalho doméstico com seus maridos. Elas são, segundo Castellanos, um colchãozinho que amortece as possíveis disputas domésticas do casamento e sua libertação implicaria a libertação também daquelas abnegadas de classes privilegiadas que se sentem confortáveis em suas posições. (Castellanos, 2003-2007) 
empregadas fantásticas, ficará grávida, seus filhos tirarão só 10 na escola, suas filhas serão como princesas, sua sogra morrerá, ela ficará viuva...uma imagem do futuro brilhante. A cabeleireira parlapatona protesta dizendo que são muito previsíveis estes sonhos, mas eles a ignoram e Lupita começa sua experiência.

Ela está vestida de noiva, sozinha com o noivo no quarto. Ele checa os gastos do casamento, um detalhe que as mulheres passam longe, enfatiza ironicamente a peça. Há uma mancha de sangue no vestido, ele lhe pergunta se foi sua primeira vez, e como a garota é claramente mais inteligente que o noivo, segue-se disso uma sucessão de piadas, como a dele perguntando se é sangue mesmo pois ele não saberia diferenciar de Catshup e ela dizendo que sim é plasma e que o teria comprado no melhor banco de sangue da cidade, que se dependesse dela teria usado melhor o dinheiro, mas que suas amigas lhe aconselharam, e que ela, como boa mulher, assim o fez. Piadas sobre a virgindade e a sexualidade das mulheres à parte, Castellanos introduz aqui pinceladas de mulher moderna assim como da hipocrisia social em negar a vida sexual das senhoritas. Da lua de mel se segue para a Anunciação, Lupita está esperando (bebê) - esperar é uma das atividades mais típicas das mulheres, afirma castellanos Castellanos en La mujer y su imagen. A partir deste momento Lupita já não precisa seduzir o marido, já conseguiu se estabelecer na situação de esposa, já tem seu lugar garantido. Sua mãe aparece. Ela corre e lhe desata a cintura, lhe joga uma camisola feia, lhe descabela, lhe ordena que se sinta mal: "sinta-se mal, se não estás mal, então toma água salgada" (Castellanos,1975, p. 320). Lupita já acessou o espaço sagrado que só as mães ocupam naquela sociedade. Assim, passa-se ao cenário Dura realidade, onde já é mãe, os filhos são pequenos e brigam. Ela é a responsável pela educação dos filhos. Estes são super travessos e Lupita monologa:

Deus me livre da babá que lhe deixa malcriados ou da escolinha que os faz insensíveis! Tudo o que tem que se sacrificar uma mãe. A mãe que aceitou a responsabilidade completa. Dos filhos. E também da casa. Graças a Deus, a minha é uma pérola (...) nem uma gota de pó. E quanto a minha pessoa, nunca descuidei da aparência. O que mais segura o marido se não uma mulher sempre bem arrumada, sempre esbelta, vibrante? Por isso é que meu pobre João está 
cada dia mais apaixonado por mim. Todas as semanas é infalível como o Papa, me traz um ramo de flores. Quando não são flores, é um agradinho. Dizem que conforme o sapo vem a pedrada. (Castellanos, 1975, p. 4024)

A autora burla do previsível que é a vida da mulher mexicana, burla do êxito e dos problemas de uma mãe para dançar conforme a música e repetir passos visivelmente não autônomos. Ela pinta traços da caricatura de um ideal de cursus de vida que para o olho crítico do espectador/leitor será um problema. Ela mostra concomitantemente o que ocorre na aparência e o que poderia acontecer se a mulher tivesse feito algo diferente, se tivesse tido coragem para agir diferentemente. Lupita em seus distintos papéis, recém casada, mulher madura e viuva, também se converte em assassina, matando o marido e a amante. Outro episódio da vida de Lupita é o de ter uma filha jovem que pretende rebelar-se contra o sistema, que não quer se casar, que quer estudar, ir à universidade, viver sua própria vida. A mãe lhe proíbe, alega que o papel de toda mulher é se manter na estrutura tradicional e manter esta como está. Desse modo, uma das estratégias argumentativas deste ato é mencionar as consequências negativas do androcentrismo para a mulher. Castellanos assim destaca os traços que segundo o imaginário coletivo mexicano uma mulher precisa para ter e para ser uma pessoa adulta e exitosa: tem que se casar, ter filhos, viver em sociedade, respeitar os costumes. Traços que se fundam na aparência, na resignação e na hipocrisia, e que ilustram, pelo que percebemos já neste primeiro ato, o quanto as mulheres - as mulheres mexicanas, latino-americanas, brasileiras e outras - se encontram (pelo menos na década de 70 do século XX) em um condição silenciosa de alienadas e vítimas sociais.

Não é meu objetivo aqui fazer uma análise do quanto as figuras caricaturais e bufônicas de castelhanos correspondem à sociedade mexicana, ou outra, mas não podemos ignorar o fato de que se tratava de uma peça que apareceu há mais ou menos meio século e apesar de se manter atual em sua temática e extremamente interessante do ponto de vista estético e literário, é uma peça que precisa ser localizada no seu espaço e tempo. Que tempo-espaço é esse? É o tempo em que transcorrem nos principais países da 
América-Latina as ditaduras militares, das quais muitos intelectuais fugiram instalando-se no México; é tempo em que Estados Unidos e Rússia estão travando a guerra fria, e isso ecoa na economia do mundo, e principalmente no México, que pela proximidade e liberalismo sempre esteve muito conectado ao país vizinho; é tempo em que a guerra do Vietnã está ocorrendo e que os intelectuais começam a questionar seus métodos em função de seus objetivos; é tempo em que as feministas, em especial as norte-americanas - entre as quais no México não houve expressividade significativa-, criavam a chamada nova onda do feminismo, resgatando as ideias do Segundo Sexo de Beauvoir e também lutando (na prática) contra as micro-opressões alocadas dentro de opressões maiores, como a econômica que passava pelo poder do Estado. Tudo isso chegava ao México, tocava o país, e Castellanos como intelectual, embaixadora, escritora engajada, que falava vários idiomas, que dava aulas como convidada nas universidades no Estados Unidos - e que também tinha depressões e momentos de profunda solidão que lhe serviam como matéria vital com a qual erigia seus textos - representava a expressão do novo e do moderno no México. Ela não era só uma escritora engajada e situada em seu tempo, ela era um exemplo, e a figura que se fez dela inspirava as garotas. Por isso talvez expressou uma grande preocupação com a receptividade do público, porque sabia que ela era um ponto de resistência.

Ainda no primeiro ato, um dos mais expressivos de toda a peça, também aparece Lupita como uma mulher envelhecida, uma viuva religiosa que vai participar de uma entrevista de televisão onde de joelhos agradece à virgen morenita de Tepeyoc por estar ali. Vai à televisão por ter ganhado o concurso de melhor mãe mexicana. $\mathrm{O}$ locutor a recebe e anuncia: "isso é a prova de que Lupita encarnou o arquétipo da mulher mexicana: sofrida, abnegada, devota" (Castellanos, 1975, p. 647). Castellanos abusa da ironia nesta imagem, retrata Lupita orgulhosa dizendo que vai interpretar seu próprio drama. Vai contar sua versão dos fatos, desde o assassinato do marido e de sua amante e secretária, cometidos por ela mesma. O apresentador do programa desconversa e lhe enche de brindes inúteis das lojas patrocinadoras do programa e a elogia por ser uma vovozinha (abuleita) que ainda tem as faculdades conservadas apesar da idade, e a infantiliza. A peça é engraçada, causa riso, o humor da 
escritora neste momento é cortante e preciso, e a abnegação feminina daquela imagens, daquele reflexo falso em um espelho falso é um retrato do sexismo escrachado e do machismo protecionista que assume e impõe que além das mulheres serem menos racionais credíveis em sua palavra, autônomas, adultas-, se forem idosas são ainda menos que as outras, sendo inferiores, vitimas e incapazes, de modo que a sociedade inteira deva protegê-las e se sentir responsável por elas.

No segundo ato, o sonho de Lupita se dará em diferentes lugares, como num circo ou um museu de cera, onde ela é a única espectadora que ao entrar para ver a mulher serpente se depara com Adão e Eva. Adão está colocando nome às coisas, ele diz que a sua companheira que ela se chama Eva, mas quando ele sai esta fala com a mulher-serpente e diz que seu nome não é esse, que o seu verdadeiro nome ela nunca dirá. A relação com La mujer y su imagen neste momento da peça se faz evidente: o que é mulher? Não é o que o homem diz que ela é, o que ela é, só ela sabe. Lupita reage à cena, dizendo que aquilo é blasfêmia. Entram em cena, então, personagens mulheres da história do México, pessoas ligadas às letras e à cultura, desfilam por ordem cronológica: Malinche, a conhecida escrava/amante de Hernán Cortés, que por falar muitos idiomas permitiu que o colonizador se comunicasse com os povos précolombianos que ali viviam; Soror Juana Inés de la Cruz, a poeta que virou freira para poder dedicar-se à literatura e não precisar casar-se com um homem; Dona Josefa Ortiz de Domínguez, quem idealizou a insurgência pela independência do México e é hoje uma heroína nacional; a imperatriz Carlota, nobre esposa do imperador Maximiliano I do México; Rosario de la Peña, a musa dos poetas e apoiadora das letras no México do final do século XIX; e Adelita, nome próprio que serviu para nomear a todas as mulheres soldadas que aderiram à revolução e lutaram com as tropas de Pancho Villa no norte do país durante a revolução. Todas elas personagens muito conhecidas dos mexicanos, estudadas na escola, senhoras que se destacaram na história, ainda que algumas de modo negativo como Malinche e Adelita. Todas elas muito lúcidas, engenhosas e ofuscadas pelos homens que elas acompanhavam ou, como o caso de Soror Juana, condenada à vida religiosa para poder exercer outra atividade que a de se casar e ser mãe. 
Através destas personagens Castellanos critica a história oficial que apesar de falar delas não as protagoniza e, ao mesmo tempo, recria esta história colocando-as como personagens principais e tão importantes na gênesis daquela sociedade. Estas mulheres não foram testemunhas passivas da história dos homens, nos explica Mercedes Serna (2014) num estudo que faz da peça de Castellanos, e Rosario Castellanos as mostra como protagonistas. Serna também sugere que Castellanos teria motivos pessoais para chamá-las, já que com seu temperamento forte e como figura pública, ela mesma, como uma mulher que ocupava lugares corriqueiramente de homens, se via retratada entre aquelas mulheres e requisitava seu espaço numa cultura e história de homens e para homens. Do mesmo modo, neste ato, ela convida seus espectadores/leitores a refletirem sobre a multiplicidade de versões que o discurso ideológico que forma a história pode ter com a ficção. Ao trabalhar com uma história oficial, masculina, e ao modificá-la literariamente, Castellanos coloca em evidencia o ideológico da história, a ficcionalidade de sua verdade e o androcêntrico de suas versões.

No terceiro ato, de repente, e de súbito, a farsa muda. Ocorre um corte de eletricidade e a viagem de Lupita é interrompida por um apagão elétrico. Diante da impossibilidade de conseguir seu penteado, começa a experimentar várias perucas de supostos papéis que poderia assumir, papéis de mulheres em profissões ou situações menos tradicionais, que trabalham e têm uma independência maior que as esposas, mas que ainda assim sofrem com a cultura que as subordina. Estas perucas são: a da mulher não-casada com sua solidão; a da prostituta e sua exclusão social; a da usurpadora, como aquela que é amante passiva de um homem só, casado e afamiliado que a sustenta e a mantém em uma casa distante da sua como em uma redoma de vidro para seu uso e abuso; e a da mulher independente e muito ocupada para ser mãe, esposa, e do lar, que são a escritora, a funcionária pública e a cientista. Entre estas últimas, a escritora traz muito de auto-biografia, podendo inclusive ser ela mesma a escritora ocupada. As passagens engraçadas e bem humoradas se mantém neste ato, como quando duas prostitutas disputam um ponto de trabalho na cidade e a mais experiente sugere à novata, muito segura de si, que se não se fizer de vítima, de pobre coitada, nunca terá clientes. Ou o diálogo da usurpadora com sua criada, a qual começa dizer à patroa 
que ela já foi empregada de muitas como ela e que sempre acontece o mesmo, o patrão começa a visitá-la menos e a desinteressar-se delas. Lupita termina correndo do salão, expulsa pela dona sob argumentos de que se trata de um salão de senhoras descentes e que ela está estragando suas perucas e Lupita gritando e argumentando que vai se pentear sozinha. A peça segue com algumas canções de tipo corridos - modalidade mexicana de canções com letras narrativas - que se referem à peça.

Castellanos com esta peça, portanto, realiza uma análise fundamentalmente sobre a mulher mexicana e as imagens que refletem seus existir, mas o que se entrelaça nestas projeções não se refere só à mulher mexicana nem somente ao México, mas à suas teorias sobre a captura do feminino a um âmbito mítico e transcendental que ao ser aplicado sobre as mulheres reais, de carne e osso, usurpa sua essência. Lupita é a mulher que passou por tantas etapas até dar-se conta, através da consciência, de que precisa fazer seu próprio penteado e agiu do mesmo modo que devem agir as mulheres que, segundo Catellanos, realizam suas próprias escolhas. Para isso, defende a escritora, não podem mais simplesmente se encaixarem em uma imagem pré-fabricada, como uma peruca que usam ou sonhando sonhos que não são seus. Quais são os sonhos de Lupita? Que sonhos tem que lhe são autênticos e originais? Qual é a verdadeira imagem da mulher? Com quê sonha e quer sonhar de modo livre?

\section{Rosario Castellanos entre o que é mulher e o devir mulher}

$\mathrm{Na}$ peça El eterno femenino a autora faz uso de um cenário de personagens burlescos, e com seus melhores recursos literários mostra que o que constitui a mulher (no singular) e o feminino é falso sobre elas (no plural), já que é um modelo que lhes é imposto, que lhes é doloroso, que lhes é opressivo, e que não lhes é verdadeiramente essencial e constitutivo. Ao mesmo tempo, ela não ignora o quanto as mulheres, inclusive ela mesma como mulher, e todas nós mulheres, estamos perdidas quanto ao que somos, pois estaríamos presas a formas de ser (mulher) coercitivas e opressoras. Por isso, além de 
reforçar a ideia de que a mulher é um produto social de uma sociedade que se erige sobre bases masculinas e masculinizadas, como já se enfatizou aqui, Castellanos também defende que é preciso uma tomada de consciência desses processo que mitificaram a mulher ao longo do tempo e a distanciaram do que ela é em sua essência, para depois disso poder dar outro passo na direção de uma nova forma de ser (mulher).

Castellanos assim responderia a pergunta inicial sobre o que é o feminino e $o$ que é a mulher de modo negativo, afirmando o que não é. A mulher não é o que os discursos da sociedade dizem que é, pois estes lhe impõe uma moralidade que se estabelece dentro de um sistema normativo que falseia seu ser. Tanto no ensaio quanto na peça que se analisou aqui fica claro que a escritora está fazendo um serviço a seus leitores ao denunciar e fazer público os processos sociais e os rituais culturais que abnegam as mulheres e que as prendem em modos de ser que não significam escolhas livres delas mesmas. Também parece claro que Castellanos, na mesma linha de Beauvoir, não assume um feminismo contra os homens, já que para ela (para ambas) não são os homens em específico que oprimem as mulheres, não é o marido que oprime a esposa - se fosse assim bastaria trocar de marido -, o que oprime as mulheres é um sistema social, é o casamento como instituição e a hierarquia que há dentro dele, e que se expressa nas ações dos homens, no agir dos Estados para com suas cidadãs, através das palavras das leis, e de todas as instituições que foram construídas sob os moldes do androcentrismo e do patriarcalismo. A luta das mulheres, assim, passa pela luta por mudar elas mesmas, mas também por mudar esta estrutura social que as faz cairem em modelos onde se encontrarão oprimidas, como sua personagem Lupita em seus sonhos opressores.

Depois de respondida a pergunta inicial, depois de conscientes e em luta contra os mecanismos que lhes oprime e lhes faz ser o que não se é, Castellanos parece que há algo que devem buscar e que é profundamente existencial delas, que é o seu ser mulher em devir, ou seja, a mulher que devem se tornar, mas que nunca foi, pois só quando puderem se fazerem a si mesmas de modo livre serão autônomas. Esta libertação, portanto, levaria as mulheres - e também os homens, pois sem mudá-los o androcentrismo nunca terminaria - a reformular a sociedade e a reformularem-se a si 
mesmas para realizarem-se plenamente como humanos. Esta formulação não é explícita no trabalho de Castellanos, senão que aparece nas entrelinhas e coincide com teses de Beauvoir, sendo defensáveis como características das concepções da escritora mexicana por considerarmos que no final de La mujer y su imagen, quando fala de uma necessidade de tomada de consciência do processo mitificador e também da rejeição ao mito, Castellanos sugere que o passo seguinte é o resgate de si mesmo, o resgate de algo essencial de si.

Ora, quando se fala em algo a ser resgatado, se supõe que há algo, ainda que somente em potência, que sairá à luz ao ser encontrado. É neste contexto que sua teoria feminista se sofistica e, acredito, que possamos pensar que este passo sucessivo à tomada de consciência, que corresponde a um resgate de si e se dá por meio de uma reconstrução de si que busca seu ser essencial, se refere à questão sobre o devir mulher presente no Segundo Sexo, a qual permite que localizemos suas concepções entre as existencialistas. Por outro lado, também parece que estas questões só eram importante para Castellanos por que elas levariam à mudanças sociais, já que o problema para ela não parecia ser teórico, mas sobretudo político. Isso coloca Castellanos entre as feministas de seu tempo, entre as mulheres que resgatam alguns temas do feminismo francês para levantar uma bandeira libertadora, mas também a coloca na passagem deste feminismo para a corrente que só aparecerá depois de sua morte e que propõe não só uma luta da mulher por um espaço social, mas principalmente pela reformulação do que se é.

A filósofa Nancy Fraser em um conhecido artigo chamado $O$ feminismo, o capitalismo e a história (2009), onde analisa um suposto fracasso do feminismo da segunda onda em concomitância com a modificação do capitalismo e o advento do neoliberalismo, ao fazer algumas reflexões menores em relação ao problema central ao qual dedica o artigo, sugere que o que se seguiu do feminismo revolucionário dos anos 70 do século $\mathrm{XX}$ teria sido a diminuição da crítica à economia dos mercados e às políticas de Estado e um aumento das demandas por reconhecimento das identidades e da diversidade. Esta luta que, segundo Fraser, caracterizava um feminismo que já não lutava só contra a autoridade tradicional e a dominação masculina, mas também demandava o reconhecimento de 
um devir livre para a mulher - sendo inclusive este apropriado pelo capitalismo tardio que criou novas forma de circulação de mercadoria, segundo a estadounidense - é um dos traços que acredito ser identificável na narrativa de Rosario Castellanos e em suas personagens de ambas as obras que apresentei aqui. Lupita, que sai correndo do salão de beleza afirmando que vai se pentear sozinha é a expressão dessa reivindicação, como vimos, e expressa também a preocupação latente nas obras da escritora pela liberdade e autonomia. Lupita não quer ter um cabelo específico que coincida com um tipo específico de mulher, mas por outro lado, ela ainda nem sabe que cabelo quer; ela só sabe e fica claro para ela depois de todos os sonhos que teve, que o que busca de si mesma, o que busca ser enquanto mulher, não lhe será imposto por nada exterior a ela. Deste modo, se por um lado, Lupita é a incarnação de teses presentes na crítica feminista de Simone de Beauvoir que defende que a verdade da mulher não está no que lhe é imposto pela sociedade mas em algo que lhe é interior e existencial, também é a expressão de uma busca por um si mesmo que poderá ser o que quiser ser, e isso deverá ser aceito. É nesta aceitação de um devir não definido da mulher (e das mulheres em sua pluralidade) que acredito que podemos falar de um vanguardismo de Castellanos em relação aos feminismos de seu tempo.

Apenas para concluir, sem maiores comentários, deixo aqui a citação de um poema publicado pela escritora em uma compilação de poemas de 1972 sob o título de Poesia no eres tu (Poesia no es tu), onde o slogan "não se nasce mulher, torna-se" nos soa como evidente, assim como é evidente a conexão com sua peça de teatro e o ensaio aqui apresentados. ${ }^{12}$

${ }^{12}$ Do original: Meditación en el umbral:/ No, no es la solución/tirarse bajo un tren como la Ana de Tolstoy/ni apurar el arsénico de Madame Bovary/ni aguardar en los páramos de Ávila la visita/ del ángel con venablo/ antes de liarse el manto a la cabeza/ y comenzar a actuar./Ni concluir las leyes geométricas, contando/ las vigas de la celda de castigo/como lo hizo Sor Juana. No es la solución/ escribir, mientras llegan las visitas,/en la sala de estar de la familia Austen/ni encerrarse en el ático/de alguna residencia de la Nueva Inglaterra/y soñar, con la Biblia de los Dickinson,/debajo de una almohada de soltera./Debe haber otro modo que no se llame Safo/ni Mesalina ni María Egipciaca/ni Magdalena ni Clemencia Isaura./Otro modo de ser humano y libre./Otro modo de ser (Castellanos, 1972) 
Meditação no umbral:/ Não, não é a solução/jogar-se debaixo de um trem como a Ana de Tolstoi/nem preparar o arsênico de Madame de Bovary/ nem aguardar nos campos de Ávila a visita do anjo com dardo/ antes de atar-se o manto na cabeça/ e começar a agir./ Nem concluir as leis geométricas, contando/ as vigas da cela do castigo/ como fez Soror Juana. Não é a solução/ escrever, enquanto chegam as visitas,/ na sala de estar da família Austen/ nem encerrar-se no sótão/ de alguma residência na Nova Inglaterra/ e sonhar, com a Bíblia dos Dickinson,/ debaixo de uma almofada de solteira./ Deve haver outro modo que não se chame Safo/ nem Mesalina nem Maria Egipcíaca/ nem Madalena nem Cemencia Isaura./Outro modo ser humano e livre. Outro modo de ser (Castellanos 1972)

\section{Bibliografia:}

Castellanos, Rosario, Mujer que sabe Latín, México: Fondo de Cultura Económica, 1973.

1975

. El eterno femenino, México: Fondo de Cultura Económica,

. "Satisfación no pedida (1971), In: Castellanos, Rosário, El uso de la palabra, México: Excélsior, $1975 \mathrm{~B}$.

. Mujer de palabras, México: Conaculta, 2003-2007. Sobre Cultura Femenina, México:, 2005.

1972

Poesia no eres tu, México: Fondo de Cultura Económica,

. "Albun de família", In: Castellanos, Rosario, obras reunidas ii: cuentos, Fondo de Cultura Económica, 2005.

Beauvoir, Simone, O Segundo Sexo 1. Fatos e mitos, Trad: Sérgio Milliet, São Paulo: Difusão Européia do livro, 4a.ed., 1970.

Cano, Gabriela. Rosario Castellanos y el feminismo de la nueva ola, In: El Universal periódico nacional, México, edição de 03 de agosto de 2018. Disponível em: http://confabulario.eluniversal.com.mx/rosario-castellanos-y-elfeminismo-de-la-nueva-ola, consultado pela ultima vez em $31 / 08 / 2018$. 
Miller, Beth. Uma Consciência Feminista: Rosario Castellanos. São Paulo: Editora Perspectiva, 1987.

Morales, Gilda Luongo, "Lección de cocina de Rosario Castellanos: lo crudo y lo cocido en el ejercicio familiar/extraño del devenir sujeto femenino" en Revista Electrónica Cyber Humanitatis de la Facultad de Filosofía y Humanidades de la Universidad de Chile, julio del año 2001

Sartre, J-P., O que é literatura?,Trad. Carlos Felipe Moisés, São Paulo: Ática, 2004.

Serna, Mercedes, "Rosario Castellanos y El Eterno Femenino". Barcelona: Anagnórisis. Revista De investigación Teatral 9, 2014.

RECEBIDO EM 06/09/2018 APROVADO EM 21/10/2018 